\title{
Guiding a Range Curriculum with an Educa- tional Needs Assessment
}

\author{
BRIEN E. NORTON AND J. NICHOLLS EASTMOND, JR.
}

\begin{abstract}
This study, undertaken as a cooperative effort between the Utah State University Range Science Department and the Instructional Development office, surveyed 138 alumni of the department to assist in the identification of needs for curriculum improvement. Strong support for the following educational concerns was evident: (1) a practical and pragmatic emphasis in the curriculum, including focus upon political and economic aspects of range management; (2) an emphasis upon communication skills, particularly oral communication, and dealing with "people problems"; (3) a field component to complement the classroom wherever possible. Findings from the study have led to the revision of two courses, the beginning of two others, and have endorsed a core course on land management policy recently introduced into the College of Natural Resources. The results of the survey have assisted curriculum development in the Range Science Department at Utah State University and may prove helpful for other educators in the field.
\end{abstract}

Periodic review and appraisal should be a normal part of higher education. In the case of a professional degree such as a Range Science BS, the faculty have a responsibility to the profession to make sure that the curriculum being offered and the standards of instruction provide adequate training for a range management career.

As philosophies of rangeland management have changed over the last half century (Harris 1977) there have been changes in the job requirements of the range manager and also in the attitude of both students and faculty toward a range education. Some components of a range curriculum seem relatively permanent, such as basic ecology and taxonomy, but others ought to respond to the needs of the times, especially in relation to land use policy and the economic environment. In a characterization by a Forest Service administrator (Arnold 1970), the 1970's was the "environmental decade," placing new and diverse demands on the land management agencies and additional pressures on livestock operators. It is reasonable to assume that in the 1980's these pressures will intensify, compounded with world energy demands.

In 1969 the Utah State University Department of Range Science undertook a self-analysis to determine what updating of the curriculum was necessary to better prepare students to find challenging employment upon graduation. As a guide to the evaluation, the opinions of graduates of the Department were surveyed by a questionnaire. The responses indicated a need to broaden the curriculum, with more emphasis on administrative and communicative skills (McKell 1970).

For the academic, the challenge in teaching such a multidisciplinary subject as range science is to strike a balance between basic and applied information, between principles and technical skills, between education in sciences and human relations. The responsibility for a satisfactory education is shared by academics

Authors are associate professor, Department of Range Science, and director, Division of Instructional Development, Utah State University, Logan, Utah 84322 .

Manuscript received December, 1979. and laymen alike, so that students who intend to call themselves range men receive a training acceptable to the profession as a whole (Box 1964).

The assignment of priorities and designation of importance in range education is a long-standing debate. Courses in hasic and applied sciences have traditionally formed the backbone of range science curricula (Heady 1961). There has been a tendency to emphasize basic sciences over technology and to stress ecological principles with which graduates can solve range management problems by a combination of a priori reasoning and experience (Tisdale 1956, Keith 1957, Washburn 1957, Morris 1961, Hooper 1969, and Arnold 1970).

In 1957 Johnson referred to range management as a "salesman's job." Communications and public relations have often been identified as an integral part of the range management profession that should receive more preparation in college (Dyksterhuis 1953, Sampson 1954, Costello 1957, and Hervey 1964). In a survey of range professionals conducted by Kienast and Scifres (1973), most respondents stressed the need for more coursework in the social sciences and for development of communicative skills, but a more extensive survey of federal agency personnel (Cook and Bonham 1974) showed that communication training is not considered to be as important as other components of the curriculum. Others have suggested that range science graduates should be more qualified in the fields of business and administration (Heady 1961, Hervey 1964, and McKell 1970). Several commentators on range education have viewed the college experience as training to equip graduates to think, solve problems, and integrate information (Sampson 1951, Costello 1957, Iehman 1966, and especially Dregne and Pettit 1972).

In 1976 the USU Range Science Department decided to reexamine its curriculum and to gauge the quality of education through a survey of its alumni. In addition to evaluation of course material and the extent to which the classes prepared students for a career, the Department was also interested in the impact of the college education on attitudes and motivation, and the value of student advising and continuing education. The assistance of the Division of Instruction Development in the USU Learning Resources program was enlisted to determine questionnaire content and design and to conduct statistical analyses of responses.

\section{Procedure}

The weakest link in the systematic development of a curriculum is often the identification and definition of the problem. As educators, we of ten assume that we have our fingers upon the pulse of the discipline, and that the structure of the knowledge required by graduates of our program is self-evident. Unfortunately, the result often reflects our past academic training far more than the training needed by graduates in a changing world. Kaufman (1972) and Witkin (1977) have suggested a technique for studying needs and systematically documenting the most critical ones for program emphasis. Focusing upon the difference between desired and perceived actual conditions, this "needs assessment" study becomes a 
means of setting program priorities. The present study, similar to one done previously in the USU Wildlife Science Department (Eastmond and Kadlec 1977), used questionnaires sent to all graduates of the department over a 15-year period for whom we had addresses.

In conducting such a study, certain assumptions are necessary. One of these is that a departmental curriculum is open to revision and that faculty will be willing to make decisions based upon alumni opinion data. Another is that the graduate population sampled is knowledgeable about student needs and that their sentiments can be gauged accurately with a questionnaire. A final assumption is that student needs in the field will not change drastically in the course of conducting the study and implementing the results. All of these assumptions seemed reasonable for this situation, but the decision was examined openly.

Working with a committee of five Range faculty members, the consultant from Instructional Development constructed an initial questionnaire and pilot-tested it with 15 graduates located in Utah and surrounding states. On the basis of this trial run, the original long questionnaire was split into two shorter survey instruments. Several modifications were made to simplify and facilitate the task of responding. Following revision, one questionnaire was distributed to half the alumni selected at random, and the other questionnaire sent to the remainder. Altogether 304 questionnaires were mailed to graduates of the Department since 1960 and a follow-up letter sent 3 weeks later.

The first questionnaire was designed to assess the graduates' impressions of various aspects of the undergraduate experience, dealing with such matters as advising, field work, course repetition, the value of a few specific courses, and some general topics. By the format of the questionnaire, alumni were given statements to which they could indicate varying degrees of agreement or disagreement.

For the second questionnaire, respondents were asked to rate the performance of the Department of Range Science in a number of areas on a five-point scale from successful to unsuccessful. These areas were technical knowledge and skills, thinking skills, communication skills, attitude and motivation, background and breadth. In addition, at the conclusion of the questionnaire, they were asked to look again at the $\mathbf{4 3}$ questions and circle the ten most critical items for curriculum improvement. The determination of critical items for the curriculum revision was based upon these ratings.

An important feature of the study was the quality assurance role played by the faculty committee. Besides reviewing the work of the consultant, the plan for sampling, and data analysis, the committee became involved with the study and familiar with the results. Thus, when the results became available for discussion by the whole Department, a cadre of faculty was available to certify the adequacy of the procedures and lend support to act upon the results. Thus, the usability of the study was enhanced.

It is worth noting that nearly two decades (1960-1976) of graduates were being asked to respond to questions about their academic program. Certainly considerable time had elapsed, especially for earliest graduates, allowing for the influence of extensive experience on the job. A number of fairly significant curriculum and faculty changes were made over that time period as well, so that all graduates were not evaluating an identical curriculum nor assessing the educational talents of the same teachers. As could be expected, a higher response rate was found for more recent graduates.

\section{Results and Discussion}

Of the 295 deliverable questionnaires, 138 or $47 \%$ were returned, 66 of the first questionnaire and 72 of the second. The response rate for alumni graduated since 1973 was considerably higher (67\%), and was similar to the response pattern for the previous Wildlife study at USU (Eastmond and Kadlec 1977). It was found that the vast majority (80\%) had not completed graduate degrees beyond the B.S. Graduates tended to work in Utah (33\%) or the surround- ing states of Idaho, Nevada, Arizona, Colorado and Wyoming $(38 \%)$.

Major employers were mainly the Bureau of Land Management (26\%) and the U.S. Forest Service (28\%), which corresponds quite closely with an employment survey of 628 range science graduates from various universities who obtained permanent positions of which 55\% were in federal agencies (Powell 1975). A number of additional employers were represented, but for comparison purposes, the remaining groups were simply categorized into "Other, Range Related" (33\%), and "Other, Non-Range Related"(13\%). In contrast to Powell's survey, relatively few USU graduates are employed by the Soil Conservation Service. Statistical comparisons were made for responses by year of graduation and by type of employer. For the most part, the statistical analyses did not reveal significant differences; exceptions are noted below.

Responses to the statements in questionnaire \#1 were scored to a maximum of 5 , representing strong agreement with the statement offered, down to a minimum of 1 , denoting strong disagreement. The highlights among the 24 items are presented in Table 1. Academic advising for undergraduates by departmental faculty received a strong endorsement, likewise the importance of a solid foundation in basic ecological concepts and principles. Some felt that more advanced training in plant ecology would be desirable, which matches the deficiency in ecology noted for range majors by Forest Service respondents in the survey by Kienast and Scifres (1973).

The notion that professors actively engaged in research are more competent and stimulating teachers (Tisdale 1956) did not score far beyond the positive side of neutral, but on the other hand, faculty who combined research and teaching careers were not criticized. Granted that there is an inherent tendency toward overall positive responses to survey questionnaires of this type due to both

Table 1. Highlights from questionnarie \#1, giving mean scores and deviations from neutral for 66 respondents. A score of 3.0 represents a neutral position (range 1.0 to 5.0), with lower values expressing disagreement and higher scores denoting agreement with the statements offered.

Deviation

Score from neutral

Advisement

Advisement is helpful

Advisement is unnecessary

3.75

1.62

$+.75$

Ecology studies

The General Ecology course is useful and satisfactory

Range majors need an advanced plant ecology course

Combining teaching with research

The best teachers do research as well

Researchers tend to neglect teaching

3.30

3.00

$+.30$

Practical and applied aspects

Undergrads should be exposed to real-life problems of ranchers and range managers

Field labs are necessary to complement. classroom

Students with urban backgrounds are handicapped

Most field labs are not applicable to everyday work

There is too much curriculum emphasis on economic and practical aspects vs. wildlife and aesthetics

Information in workshops and shortcourses designed for govt. agency staff should be available to undergraduates

$1 * 3.49$

1*Significant difference $(p<.05)$ among groups based on year of graduation (1960-64, 1965-72, 1973-76). 
respondent generosity and the "halo effect" (Cronbach 1970, p. 572 ), we may conclude that graduates did not perceive any difference in the teaching abilities of professors involved with research compared to those who are not.

The highest endorsement in this first questionnaire was for a practical and pragmatic emphasis in the undergraduate curriculum, as reflected in the six entries under the relevant heading in Table 1. Though a statistical test showed a significant difference $(p<.05)$ between age groups for only the last two items in Table 1, there was a consistent tendency for recent graduates to rate practical training at a higher level than graduates of at least 10 years standing. There could be several reasons for this: (1) the older graduates are more conservative in expressing their opinions, with less inclination to mark the extreme scores on the available range; (2) older graduates have been promoted from "field" positions to desk jobs where the problems are largely administrative; (3) new graduates have a heightened sensitivity to on-the-job deficiencies when fresh from campus; (4) the recent graduates are expressing a backlash against the popular emphasis of the 1960's on aesthetic and somewhat intangible value judgments of range utility.

Students generally possess a practical perception of the goals of a university education (e.g., Collins 1956), but the influx of students from a broader spectrum of society particularly evident in recent years led Cross (1971) to observe that

... New Students are positively attracted to careers and prefer to learn things that are tangible and useful. They tend not to value the academic model of higher education that is prized by faculty, preferring instead a vocational model that will teach them what they need to know to make a good living. (p. 159)

It is clear that a satisfactory range science curriculum must provide training in useful marketable skills; as Sampson (1954) and Hervey (1964) have pointed out, a curriculum should be shaped by employment opportunities.

Recipients of the second questionnaire were asked to rate the success of the Department in providing students with certain skills, attitudes, or perspectives. Answers were scored from 1 to 5, representing performance ratings of very unsuccessful to very successful. A "don't know" column was provided and given a score of 0 . The ratings of the most important questions (summarily paraphrased) are given in Table 2 arranged in order of score, and designated by group.

Skills associated with writing, use of English, reading, and understanding professional materials appear in the top half of the list. Skills associated with communication, especially at the verbal level, appear with low ratings in the bottom half, an echo of the earlier survey (McKell 1970) and an indication that oral language skills are getting less attention than they deserve. This particular outcome was confirmed by the answers to Free Response questions in both questionnaires in which communication techniques and handling "people problems" were identified as areas with insufficient preparation at the undergraduate level. The future success of a range student depends fully as much upon being able to intelligibly express and convince others of range facts learned as upon knowing the facts (Dyksterhuis 1953, among others).

Graduates indicated satisfactory introduction at college to utilizing professional publications. This may, of course, be a commentary on textbook study and library work associated with most university curricula and not a reflection of education in the Department of Range Science, per se. It may also reveal a low level of involvement in reading and sophisticated writing on the part of alumni. Whatever the case, it would seem that graduates believe that reading and writing skills do not need special attention in curriculum revision, which is borne out by the data in Table 3 . In the survey of range professionals conducted by Cook and Bonham (1974), English was identified by only $2.1 \%$ of respondents as a shortcourse needed for improving the ability of Range Conservationists to carry out their assignments.

Items in the Knowledge category were rated from excellent through to very poor. Some of those in the lower part of the scale represent special aspects of range management that have assumed importance in only the last 5 or 10 years, such as attention to

Table 2. Highlights from questionnaire \#2, describing the performance of Range Science Department by mean scores and deviations from neutral for 72 respondents. A score of 3.0 represents a neutral position (range 1.0 to 5.0 ) with deviations expressing the relative success or failure of the faculty in teaching performance.

\begin{tabular}{|c|c|c|c|c|c|c|}
\hline \multirow[b]{2}{*}{$\begin{array}{l}\text { Adequacy } \\
\text { of } \\
\text { instruction }\end{array}$} & \multirow[b]{2}{*}{ Skill or knowledge } & \multirow[b]{2}{*}{$\begin{array}{l}\text { Mean } \\
\text { score }\end{array}$} & \multirow[b]{2}{*}{$\begin{array}{r}\text { Deviation } \\
\text { from } \\
\text { neutral }\end{array}$} & \multicolumn{3}{|c|}{ Talent cluster of educational categories } \\
\hline & & & & $\begin{array}{c}\text { Reading } \\
\text { and } \\
\text { writing }\end{array}$ & $\begin{array}{l}\text { Oral } \\
\text { Communica- } \\
\text { cation } \\
\text { (Public } \\
\text { relations) } \\
\end{array}$ & $\begin{array}{l}\text { Knowledge } \\
\left({ }^{*} \text { Strong }\right. \\
\text { field } \\
\text { compo- } \\
\text { nent })\end{array}$ \\
\hline Excellent & Range plant identification & 4.64 & +1.64 & & & $\mathrm{X}^{*}$ \\
\hline Good & $\begin{array}{l}\text { Multiple use management } \\
\text { Knowledge of information sources } \\
\text { Assimilating ideas from publications } \\
\text { Record-keeping and documentation } \\
\text { Assessing range condition and trend }\end{array}$ & $\begin{array}{l}3.78 \\
3.74 \\
3.69 \\
3.56 \\
3.54\end{array}$ & $\begin{array}{l}+.78 \\
+.74 \\
+.69 \\
+.56 \\
+.54\end{array}$ & $\begin{array}{l}X \\
X \\
X\end{array}$ & & $\mathrm{X}^{*}$ \\
\hline Fair & $\begin{array}{l}\text { Writing reports } \\
\text { Solving real-life management problems } \\
\text { Applying math and stats } \\
\text { Use of English } \\
\text { Determining optimum range utilization }\end{array}$ & $\begin{array}{l}3.48 \\
3.46 \\
3.41 \\
3.39 \\
3.38\end{array}$ & $\begin{array}{l}+.48 \\
+.46 \\
+.41 \\
+.39 \\
+.38\end{array}$ & $\mathrm{x}$ & & $\begin{array}{l}\mathrm{X}^{*} \\
\mathrm{X} \\
\mathrm{X}\end{array}$ \\
\hline Marginal & $\begin{array}{l}\text { Communicating research and technical } \\
\text { information } \\
\text { Justifying management decisions to public } \\
\text { Teaching range managment practices } \\
\text { Economic aspects } \\
\text { Range livestock production }\end{array}$ & $\begin{array}{l}3.28 \\
3.26 \\
3.26 \\
3.22 \\
3.12\end{array}$ & $\begin{array}{l}+.28 \\
+.26 \\
+.26 \\
+.22 \\
+.12\end{array}$ & & $\begin{array}{l}X \\
X \\
X\end{array}$ & $\begin{array}{l}\mathbf{X} \\
\mathbf{X}\end{array}$ \\
\hline Poor & $\begin{array}{l}\text { Persuasion techniques } \\
\text { Energy development and impacts } \\
\text { Endangered species } \\
\text { Overcoming political obstacles } \\
\text { Use of computers }\end{array}$ & $\begin{array}{l}2.97 \\
2.42 \\
2.39 \\
2.17 \\
1.83\end{array}$ & $\begin{array}{l}-.03 \\
-.58 \\
-.61 \\
-.83 \\
-1.17\end{array}$ & & $\mathrm{x}$ & $\begin{array}{l}\mathbf{X} \\
\mathbf{X} \\
\mathbf{X}\end{array}$ \\
\hline
\end{tabular}


endangered species and impacts of energy development. The introduction of computer technology to range science education is too recent to justify evaluation; its appearance on the bottom of the list is likely more of a check on the validity of the responses than a commentary on the value of training in the use of computers.

An advanced course in range livestock production was being developed at the time the questionnaires were distributed and has since been established in: the curriculum, rectifying, hopefully, the low rating for this field of knowledge.

Economic aspects of range management did not receive a high performance score overall, but analysis by year of graduation revealed that recent graduates rated this area of instruction with a significantly higher score (4-16) than the classes of 1960 through 1972. This trend may be understood in the context of a change during the 1970's toward more emphasis on management and less attention to economic theory. Courses in this area now include real-life problem-solving, determining optimum range utilization and weighing alternative use strategies. Although additional training in the fields of economics and politics was at the top of the list of targets for future curriculum emphasis (Table 3), the economics side of the proposition received only mild support from recent alumni.

\section{Table 3. Analysis of questionnaire items identified by 59 respondents as targets for future emphasis to improve the educational program in the Department.}

\begin{tabular}{|c|c|c|c|c|}
\hline Subject area & $\begin{array}{c}\text { Number } \\
\text { of } \\
\text { specific } \\
\text { questions } \\
\text { in subject } \\
\text { area }\end{array}$ & $\begin{array}{c}\text { Mean } \\
\text { number } \\
\text { of } \\
\text { checks }\end{array}$ & $\begin{array}{c}\text { Mean as } \\
\% \text { of } \\
\text { respon- } \\
\text { dents }\end{array}$ & $\begin{array}{l}\% \text { of re- } \\
\text { spondents } \\
\text { who } \\
\text { checked in } \\
\text { subject } \\
\text { area } \\
\text { (intensity } \\
\text { rating) }\end{array}$ \\
\hline
\end{tabular}

Ability to deal with economic considerations and political obstacles

2

Practical application of range science to field problems

3

Ability to argue persuasively and convince both lay and professional people

Multiple use concepts, policies and measures

Range plant identification and condition assessment

Understanding ecosystem properties and utilization for optimum production

Range livestock production

Energy development and range impacts

Ability to write well

3

$2 \quad 18$

31

18.5

31

Use of stats and field smapling skills

Use of computer to solve problems

Keeping up with professional literature and using the information

Problems of endangered species
Education in knowledge with a strong field component received general approbation from the alumni. When the scores of individual items are checked on the scale of one to five, however, the approval is clearly qualified, and there is obviously room for improvement in those areas where the Department should be most competent and most highly recognized, such as assessing range condition and trend.

The responses to the second questionnaire summarized in Table 2 are useful in evaluating teaching performance but provide little by way of direction for curriculum revision. For example, the low score for performance in teaching computer skills does not automatically mean that this subject should therefore be dropped from the curriculum. Guidelines for possible changes in the curriculum were obtained by asking alumni to identify ten of the total 43 questions (in the second questionnaire) as items deserving emphasis for future education development in the Department. A summary analysis of critical items is given in Table 3 .

Even though plant identification and condition assessment scored well on the performance part of the questionnaire, they also ranked high in emphasis for future improvement, which underlines their centrality to a college range training.

It is interesting to note that the impact of energy development is recommended for future curriculum emphasis by a quarter of the respondents, while problems of endangered species, another popular issue of the current decade, was scarcely marked.

The use of statistics and field sampling techniques did not rank very high on the list in Table 3 , which could mean that instructional coverage is already quite adequate, even though performance in this area is not outstanding (Table 2).

Three quarters of the alumni marked for future educational emphasis questions dealing with economic considerations and political problems in range management, the pragmatics of range science, and persuasive communication. A need was identified for more education in multiple use policies and practices, and for an ecosystem approach to optimum utilization.

Rangelands that once were the almost exclusive province of ranchers, prospectors, and provident hunters are now the playground of American suburbia and often the watershed resource for distant urban sprawls. This trend in variable use adds capricious expectations to the traditional demands of management practice, and resource management becomes a complicated political exercise (Harris 1977). The range manager of today may be confronted with unforeseen management situations in the decades ahead, such as the evolution of ranching into a form of conspicuous consumption like owning one's own aircraft for the life style it provides rather than for an income base (Cla wson 1972), a terminal case of change in rangeland values. The range graduate must be flexible and adaptable to the new politics of public land management. Several years ago McGuire (1973) concluded that "no longer can we rest our case solely on professional judgement or technical facts," we also need diplomacy, courtesy and persuasive arguments to address the claims of those who do not comprehend technical facts and may not respect professional judgment.

\section{Aftermath}

It has been 2 years since the data from this study were first reported at the annual departmental retreat. The findings provoked considerable interest among faculty at that time and the study has since become part of the department's data arsenal for such items as an accreditation self-study report written in 1979, or course revision for individual professors.

As a department, the decision to add several new courses is the most tangible evidence that this study made a difference. The first curriculum change to be implemented as a result of the questionnaire was the introduction of a course specifically designed to teach communication techniques in natural resource management. A plant taxonomy course followed, and there has been discussion of more instruction in range ecology. The advanced course in range livestock production has already been mentioned. The highly 
important need areas of economic and political considerations are being dealt with through a three-course, core curriculum for the entire Natural Resources college, since these issues certainly transcend departmental lines (Eastmond and Kadlec 1977). In any case, the direct outcomes and subsequent spinoffs from this study have been considerable.

It is noteworthy that no courses have been dropped specifically because of this study, which, although logical, reflects a very real situation in curriculum change, namely that it is easier to enthusiastically support the new rather than eliminate the old. More likely is the prospect of weeding out courses based upon low enrollments in a future departmental housekeeping move.

It should also be noted that the Range Science Department has in no way felt limited by the findings of the study. For example, there was little indication from the questionnaire that a course in international aspects of range management was deserving of attention, with only five respondents citing this item as critical. And yet a senior level course dealing with these international issues has been recently introduced and appears relatively popular. In other curriculum areas as well, this survey has been taken as indicative but not definitive, as pointing out possible directions but certainly not representing the final word. The opinions of alumni as reflected in this survey are taken as one important perspective, a perspective which is often lacking in departmental decision making, but a perspective which is not without its own limitations.

\section{Literature Cited}

Arnold, R.K. 1970. Changing educational needs for research, teaching, and extension. J. Range Manage. 23:330-333.

Box, T.W. 1974. Trends in range management education. J. Range Manage. 17:237-241.

Clawson, M. 1972. Range management in the United States for the next one to three generations. J. Range Manage. 25:328-332.

Collins, R.A. 1956. A student looks at range education. J. Range Manage. 9:207-208.

Cook, C.W., and C.D. Bonham 1974. An analysis of range conservation academic training. J. Range Manage. 27:480-483.

Costello, D.F. 1957. Range management education. V. College training for range management students: an employer's view. J. Range Manage. 10:121-122.
Cronbach, L.J. 1949. Essentials of Psychological Testing. Harper and Row, New York.

Cross, K.P. 1971. Beyond the Open Door: New Students to Higher Education. Jossey-Bass, San Francisco.

Dregne, H.E., and R.D. Pettit 1972. Environment, ecology, and range management curricula. J. Agron. Educ. 1:72-75.

Dyksterhuis, E.J. 1953. Some notes and quotes on range education. J. Range Manage. 6:295-298.

Eastmond, J.N., and J.A. Kadlec 1977. Undergraduate educational needs in wildlife science. Wildlife Soc. Bull. 5:61-66.

Harris, G.A. 1977. Changing philosophies of rangeland management in the United States. J. Range Manage. 30:75-78.

Heady, H.F. 1961. Range curricula. J. Range Manage. 14:301-314.

Hervey, D.F. 1964. The challenge of the future as viewed by educators in range schools. J. Range Manage. 17:119-121.

Hooper, J.F. 1969. The uniqueness of range management. J. Range Manage. 22:67-68.

Johnson, R. 1951. Range education. J. Range Manage. 4:315-318.

Kaufman, R.A. 1972. Educational System Planning. Prentice-Hall, Englewood Cliffs, N.J.

Keith, T.B. 1957. Range management education. III. Animal husbandry training for the range livestock producer. J. Range Manage. 10:23-25.

Kienast, C.R., and C.J. Scifres 1973. Survey of professional attitudes toward range science education and training. J. Range Manage. 26:161164.

Lehman, A. 1966. A technical education isn't enough. J. Range Manage. 19:171-172.

McGuire, J.R. 1973. Status and outlook for range in the new politics. J. Range Manage. 26:312-315.

McKell, C.M. 1970. Range management at the crossroads. J. Range Manage. 23:222-223.

Morris, M.W. 1961. Range management as a profession. J. Range Manage. 14:3-5.

Powell, J. 1975. Who hires them? A survey of range graduate employment. Rangeman's J. 2:47-49.

Sampson, A.W. 1951. Range management education. J. Forest 49:507-510.

Sampson, A.W. 1954. The ed ucation of range managers. J. Range Manage. 7:207-212.

Tisdale, E.W. 1956. Range management education. II. College training in range management. J. Range Manage. 9:218-219.

Washburn, L.E. 1957. Range management education. IV. The educational problem common to range management and animal husbandry. $J$. Range Manage. 10:79-82.

Witkin, B.R. 1977. Needs assessment Kits, Models and Tools. Educational Technology 17:11, p. 5-18. 